\title{
フラップゲートおよびナップの自励振動
}

\section{SELF-EXCITED OSCILLATION OF FLAPGATE AND NAPPE}

\author{
荻原国宏* \\ By Kunihiro OGIHARA
}

\begin{abstract}
Self-excited oscillations of flapgate are obseved in many intake structures such as weirs and dams. Recently this phenomenon occures in rubber dam which is made by flexible rubber sheets. This oscillation has been analised partly about ten years ago by author. But this analysis can not make clear all of the occurence of self-excited oscillation in flapgate and nappe oscillations.

In this time, another analysis has been done on this phenomenon by adding to the former amalysis and the good results can be derived which are able to explain the almost of the unstalble phenomena on the flapgate and nappe oscillations. Namely, my experimental results from 1972 to $1974, H$. Ivan Schwartz's “ $K+1 / 4$ " law and E. Pariset's “ $K+3 / 4$ $+\beta$ " law are certified crearly by this analysed results.
\end{abstract}

\section{1.はじめに}

フラップゲートの自励振動, およびナップの振動につ いては，以前に概論的討論を加えて，現象を明確にする ことができたと考えている゙．しかしながらそのときに も説明できない不安定現象があったわけである．たとえ ば固有周期の半周期の落下時間 (水のゲート先端より水 面までの到達時間）においても不安定振動が発生するこ とが実験では判明していたわけであるが, 理論解析のつ めが十分でなく，説明できないままであった。

1983 年の夏に, 台湾の成功大学における講演のため の原稿作成および, 講演時に, 先に発表した論文の解析 に目を通していたところ, 新しく, 整理をしなおすこと によって, この不安定現象を解明する手法のあることが 判明した。

そこで，このアイデアに基づいて，この現象の不安定 条件を, 改めて求め, 実験結果との比較をしてみた. そ の結果, 新しい事実も判明したので,ここにまとめてみ た.

* 正会員 工博 東洋大学教授 工学部土木工学科 （３50埼玉県川越市鲸井中野台 2100）

\section{2. 自励振動の方程式}

フラップゲートの自励振動の方程式の誘導については 以前に求めてあるので，ここでは，その考え方と結果に ついてまとめておく. フラップゲートは, 下端のヒンジ を回転軸とする振動系を構成する。これに作用する振動 外力は，ゲート上面および下面に作用する圧力変動であ り,これのとらえ方が重要な点である。

ゲートの慣性モーメントを $I$, ゲートの先端でばね定 数 $k$ のばねで支持されているとし, $R_{\theta}, F(\theta, t)$ をそ

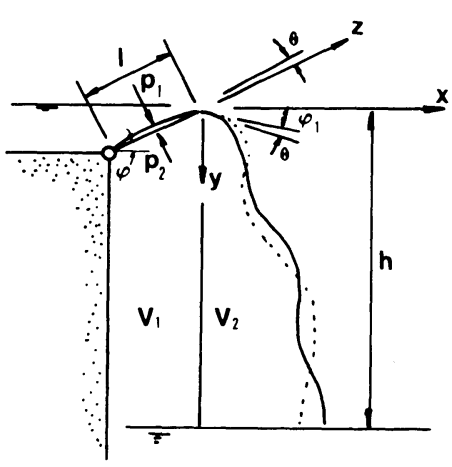

Fig. 1 Flapgate and Nappe. 
れぞれ, 粘性減衰係数, 振動外力とすると, 振動方程式 は

$$
I \ddot{\theta}+R_{\theta} \dot{\theta}+k l^{2} \theta=F(\theta, t)
$$

となる.lはゲートの扉高である.

振動外力のうち，ゲート下面に作用する圧力変動が キーポイントである．これは，ゲート先端より流出する 水流の方向が変動するために，ナップが脈動すると考え る.この脈動によって, ゲート下の空気の体積が変動し, 圧力変動を発生させると考える.

ゲート上面の圧力変動は, ゲートの運動に伴う流体力 によるものであると考え，振動外力を求めると次のよう になる。

$$
\begin{aligned}
F(\theta)= & \frac{R T}{V^{2}} \frac{B^{2} l^{2}}{2}\left[\int_{0}^{x_{1}} x \theta\left(t-\frac{x}{v_{0} \cos \varphi_{1}}\right) d x-\frac{l^{2}}{2} \theta\right] \\
& -\int_{0}^{l} B \frac{d P_{1}}{d \varphi} z d z \cdot \theta \cdots \cdots \cdots \cdots \cdots \cdots \cdots \cdots \cdots \cdots \cdots \cdots \cdots \cdots \cdots \cdots(2)
\end{aligned}
$$

この式の第 1 項が，ナップの脈動による振動外力であ り，第 2 項が，ゲート上面に働く生力 $P_{1}$ による振動外 カである。

$B$ はゲートの幅 (ゲート長) であり， $V$ はゲート下 面および，ナップ下の空気の体積である， $R, T$ は気体 定数および, 絶対温度である. 式（2）を式（1）に代 入して $I$ で両辺を割りパラメーターを整理すると次の 式が得られる。

$$
\begin{gathered}
\ddot{\theta}+2 \gamma \dot{\theta}+\omega_{n}^{2} \theta=M_{1} \int_{0}^{x_{1}} x \theta\left(t-\frac{x}{v_{0} \cos \varphi_{1}}\right) d x \\
\ldots \ldots \ldots \ldots \ldots \ldots \ldots \ldots \ldots \ldots \ldots \ldots \ldots \ldots \ldots \ldots \\
2 \gamma=\frac{R_{\theta}}{I}, \quad M_{1}=\frac{1}{I} \frac{R T}{V^{2}} \frac{B^{2} l^{2}}{2} \\
\omega_{n}^{2}=\frac{1}{I}\left[k l^{2}+\int_{0}^{l} B \frac{d P_{1}}{d \varphi} \cdot z d z+\frac{R T}{V^{2}} \frac{B^{2} l^{4}}{4}\right]
\end{gathered}
$$

水の下流面に落下する位置とゲート先端との水平距離 $x_{1}$ は, 水が自由落下運動をするものとして, 落下高さ $h$ との関係で, 次のように求められる.

$$
x_{1}=\sqrt{\frac{2 h}{g}} \cdot v_{0} \cos \varphi_{1}
$$

\section{3. 自励方程式の特性方程式}

このようにして式（３）のような自励振動の方程式が 求まったので, これの特性を求めるために, 振動方程式 の特性根を求めることにする.

まず式（3）の特性方程式を求める。この式にラプラ 不変換をし, $t=0$ で $\theta=0$ とすると次式が求まる.

$$
\begin{aligned}
& F(s)\left[s^{2}+2 \gamma s+\omega_{n}^{2}-M_{1}\left\{\frac{c^{2}}{s^{2}}\left(1-e^{-\frac{x_{1}}{c} s}\right)\right.\right. \\
& \left.\left.-\frac{c}{s} x_{1} e^{-\frac{x_{1}}{c} s}\right\}\right]=\theta^{\prime}(0)
\end{aligned}
$$

ただし

$$
c=v_{0} \cos \varphi_{1}
$$

したがって, 特性方程式は

$$
\begin{aligned}
& z(s)=s^{2}+2 \gamma s+\omega_{n}^{2}-M_{1}\left\{\frac{c^{2}}{s^{2}}\left(1-e^{-\frac{x_{1}}{c} s}\right)\right. \\
& \left.-\frac{c}{s} x_{1} e^{-\frac{x_{1}}{c} s}\right\}=0
\end{aligned}
$$

となる。

この方程式の特性根を求めて, その実部の正負より不 安定および安定条件を求めればよいが, 式（8）が無理 方程式であるので，単純にはゆかない.

そこで複素平面の写像の考え方を使い, 特性根を

$$
s=\sigma+i \omega
$$

と表わし, 式（8）に，これを代入し，実部および虚部 に分ける.

$z(\sigma+i \omega)=X+i Y$

このようにすると, $s$ 平面上の点は $z$ 面上の点に, 写像関数 $z(s)$ によって写像されることになる.しか も特性根 $s$ は $\boldsymbol{z}(s)$ を 0 とすることから， $s$ 平面上の 特性根はすべて, $z$ 平面上の原点に写像されてしまうこ とになる。

さて, $s$ 平面での特性根のうち $\sigma>0$ のものは不安定 に， $\sigma<0$ のものは安定に相当しているので， $\sigma=0$ の場 合が, 安定, 不安定の限界条件を示していることになる. すなわち

$s=i \omega$

の条件は, 自励振動の発生条件 $(\sigma>0)$ の限界を与え ることになる.

すなわち， $s$ 平面上で，これは $i \omega$ 軸そのものであり， この軸より右は不安定，左は安定ということになる.

したがって $i \omega$ 軸上を原点 0 より $\omega$ の増加方向にたど るとき，右側にある根は不安定条件，左側にある根は安 定条件を与える.

そこで，式（11）が $z$ 面上に写像されたときも，同 じことになり， $\omega$ が増加する方向に写像された曲線上を 進むとき，原点（特性根を示す）が右にあるか, 左にあ るかで，不安定，安定条件を決めることができる.

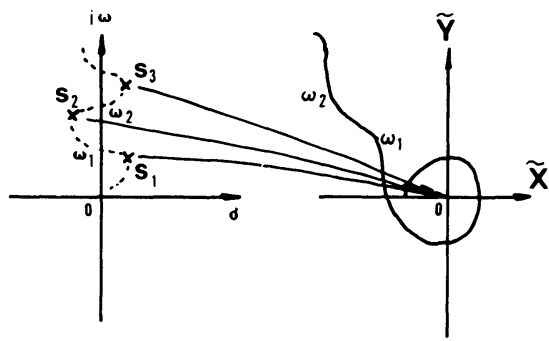

Fig. 2 Relations between $\tilde{X}, \tilde{Y}$ and $s$. 
まず, 式（11）が $z$ 面上に写像される座標を求める よう.

$$
\begin{aligned}
& \beta=\frac{x_{1}}{c}, \quad A=\frac{2 \gamma}{M_{1} x_{1}^{2} \beta}, \quad C=\frac{1}{M_{1} x_{1}^{2} \beta^{2}} \\
& x=\omega \beta, \quad x_{n}=\omega_{n} \beta
\end{aligned}
$$

とおき

$$
\begin{aligned}
\tilde{X}= & \frac{X}{M_{1} x_{1}^{2}}=\operatorname{Real}[z(i \omega)]=C\left(x_{n}^{2}-x^{2}\right) \\
& +\frac{1-\cos x}{x^{2}}-\frac{\sin x}{x}=F_{2}(x) \cdots \cdots \cdots \\
\tilde{Y}= & \frac{Y}{M_{1} x_{1}^{2}}=\operatorname{Imag}[z(i \omega)]=A x+\frac{\sin x}{x^{2}} \\
& -\frac{\cos x}{x}=F_{1}(x) \cdots \cdots \cdots \cdots \cdots \cdots \cdots \cdots \cdots \cdots \cdots \cdots
\end{aligned}
$$

が得られる.

さて,この $\tilde{X}, \tilde{Y}$ は $z$ 面上で, Fig. 3 のような関係 になっており， $x$ が $d x$ 増加したときに， $\tilde{X}, \tilde{Y}$ がそれ ぞれ $d \tilde{X}, d \tilde{Y}$ 増加するとすれば, $(\tilde{X}, \tilde{Y})$ より $(\tilde{X}+d \tilde{X}$, $\tilde{Y}+d \tilde{Y})$ の点へのベクトルが原点に対してどのように なっているかを考えればよい。

$$
\begin{aligned}
& \text { そこで } \\
& \begin{aligned}
\frac{d \tilde{X}}{d x} & =-2 C x-\frac{2}{x^{3}}+\frac{2-x^{2}}{x^{3}} \cos x+\frac{2}{x^{2}} \sin x \\
& =F_{4}(x) \cdots \ldots \ldots \ldots \ldots \ldots \ldots \ldots \ldots \ldots \ldots \ldots \ldots \ldots \ldots \ldots \ldots \ldots \ldots \ldots \ldots \ldots \ldots \ldots \ldots \ldots \\
\frac{d \tilde{Y}}{d x} & =A-\frac{2-x^{2}}{x^{3}} \sin x+\frac{2}{x^{2}} \cos x=F_{3}(x) \cdots \cdots
\end{aligned}
\end{aligned}
$$

とおき, $F_{1} \sim F_{4}$ までの関数が, $x_{n}, A, C$ のパラメータ一 で, どのような值をとり, $(\tilde{X}, \tilde{Y})$ より $(\tilde{X}+d \tilde{X}, \tilde{Y}$ $+d \tilde{Y})$ へのベクトルが時計回りか反時計回りかを判定 すればよい.

この前の解析では，このベクトルが第 1 から第 4 像限 でどのようになるかを個別に考えて，結論を出して，不 安定条件として

$$
x=n \pi, \quad n=1,2,3 \cdots
$$

の条件および，自励振動の場合には

$$
x=x_{n}=2 n \pi
$$

であることを求めたわけである.

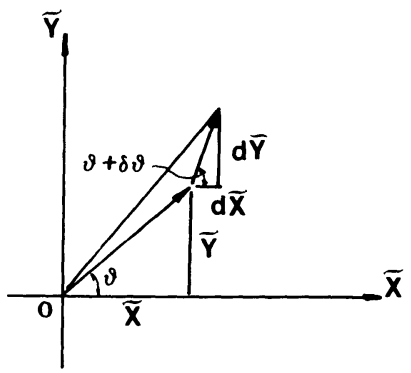

Fig. 3 Vector $X, Y, d X$ and $d Y$.

\section{4. 不安定条件}

さて，結局，不安定条件は $z$-面上でのベクトル $d \boldsymbol{r}$ (Fig. 3) が，原点 0 に対して時計方向に回るか, 反時 計方向に回るかで, 原点を右にみるか, 左にみるかで決 まることになる.

このことは $(\tilde{X}, \tilde{Y}),(d \tilde{X}, d \tilde{Y})$ で作る 2 つのべク トルの間では， $x$ 軸となす角の関係より

$$
\begin{aligned}
& \tan \theta=\frac{\tilde{Y}}{\tilde{X}}=\frac{F_{1}(x)}{F_{2}(x)} \ldots \ldots \ldots \ldots . \\
& \tan (\theta+d \theta)=\frac{d \tilde{Y}}{d \tilde{X}}=\frac{F_{3}(x)}{F_{4}(x)} .
\end{aligned}
$$

の関係が得られ，結局，時計方向の回転は

$$
\tan (\theta+d \theta)<\tan \theta
$$

であることになる。したがって

$$
\frac{d \tilde{Y}}{d \tilde{X}}<\frac{\tilde{Y}}{\tilde{X}}
$$

が不安定条件になる、よって

$$
G(x)=\tilde{X} \cdot d \tilde{Y}-\tilde{Y} \cdot d \tilde{X}<0 \cdot
$$

で条件が決定できることになる，さらに自励振動の場合 は $x=x_{n}$ とすればよい. $F_{1} \sim F_{4}$ で書くと

$$
G(x)=F_{2}(x) \cdot F_{3}(x)-F_{1}(x) \cdot F_{1}(x)
$$

である。

式 (24) には $x, x_{n}, A, C$ のつのパラメーターが 含まれている.したがって,これらのパラメーターによっ て条件がどのように変わってくるかを検討すればよい.

まず，始めに $x_{n}=1(2 \pi)$ として $C=0.00001,0.001$ ， 0.1 とした場合の $G(x)$ の変化について調べてみるこ とにした.

式 $(13) \sim(16)$ の各式は, $x^{2}, x^{3}$ で割った形となっ ているので, $x$ が 0 に近いときに非常に大きな值になっ てしまい,グラフ表示しにくいので, 式 (13), (14) に は $x^{2}$ を, 式 $(15),(16)$ には $x^{3}$ をかけて, 扱うこと にする。

すなわち

$\bar{G}(x)=x^{5} \cdot G(x)$

の形でグラフ表示する. $x>0$ の範囲で考えるので, $G(x)$ $<0$ は $\bar{G}(x)<0$ に対応できることになる。

さて, $A=0.0001$ から 0.1 までの間を 10 点選び，三 次元グラフ表示したのが，Fig. 4 のグラフである.

横軸は $x$ の值を示しており $x=0$ より $x=4$ までの計 算結果が示されている.

縦軸は式（25）で示す $\bar{G}(x)$ の值である.この值が 負の範囲が不安定振動になっていることになる.

このグラフから次のようなことがわかる.

イ）共通していえることは，Aの值が大きくなるに 従って, $\bar{G}(x)$ の値は変動が小さくなってくる. 
口) $x=1,2,3,4$ の付近で, $\bar{G}(x)$ が+よりーに変 化している.

八) $x=n+1 / 4, n+3 / 4$ の付近では+側より一側へ, または逆に一側より+側へと急変するところが発生して いる.

二） $x_{n}=1$ の場合を示してあるが，他の場合でも， $x$ $=x_{n}$ を境にして，グラフの傾向は逆転している．すな わち， $x$ の増加方向にたよ゙るとき，八）に述べた傾向が +よりーに変化していたのがーより+に変化するように なる。

ホ） Cの值が大きくなるに従って, 安定の部分が増
また同時に安定の範囲は少なくなってきている.

加してくる.

Fig. 4 のグラフの横軸は, $x / 2 \pi$ の値を表示している. 次に自励振動の発生する条件，すなわち，振動系の固 有振動の周期で振動が発生し，不安定振動になる条件を 求めてみる.

式 (25) で $x=x_{n}$ として, $\bar{G}(x)$ の值を求めてみた. 結果はFig. 5 である. 表示の仕方は, Fig. 4 と同じであ る.

これらのグラフと Fig. 4 のグラフと比較してみると

1) $C=0.00001$ の場合のグラフはよく似た傾向を示 しているが, $x=1,2,3,4$ の付近で，対称形をなすよ うにピーク值を示している点が異なっている.

2) $C$ の值が大きくなると, $\bar{G}(x)$ の值 C 0.00001

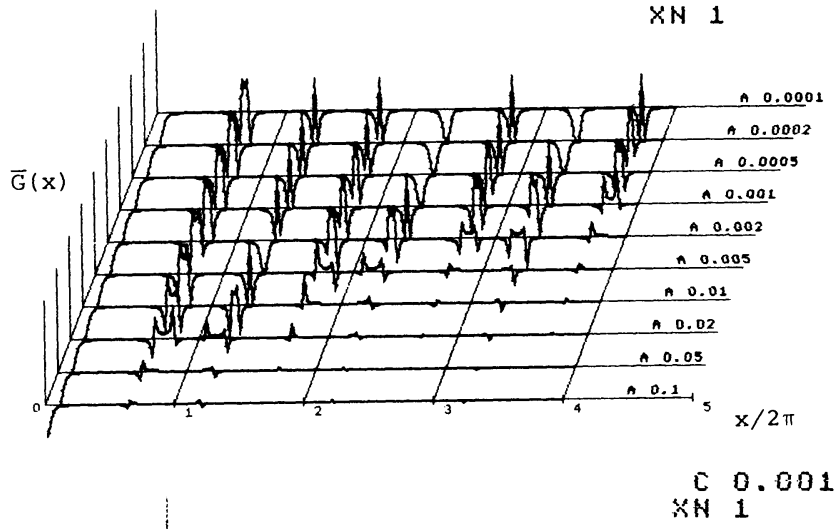

は小さくなる傾向を示しており, $C=0.1$ の 場合には，ほとんどの範囲にわたって負の值 を示している.

3) $n+1 / 4, n+3 / 4$ の付近でマイナスの ピークが出ているのは, 先の Fig. 4 の場合亡 同じ傾向である。

4) $C=0.00001$ の $A$ の值の小さい部分 で, $x=2+1 / 4,3+1 / 4, C=0.001$ の $x=1$ $+1 / 4$ の付近では, 安定の部分がなく, 不安 定でマイナスのピークが現われている.

このようにしてみると，パラメーター $C$, $A, x_{n}$ の組合せによって, かなり様相が変 わってくることがわかった.

そこで，もう少し考え方，見方を変えてみ る.

式（24）で $G(x)$ の值を求めるのでなく, $G(x)=0$ が安定, 不安定の限界条件を与え るのであるからこの条件より，Aの值を 定めることにする.

すなわち式 (14), 式 (16) で， $A$ の含ま れていない項を $\tilde{Y}_{1}, d \tilde{Y}_{1}$ とおくと

$\tilde{Y}=A x+\tilde{Y}_{1}$

$d \tilde{Y}=A+d \tilde{Y}_{1}$

C 0.1

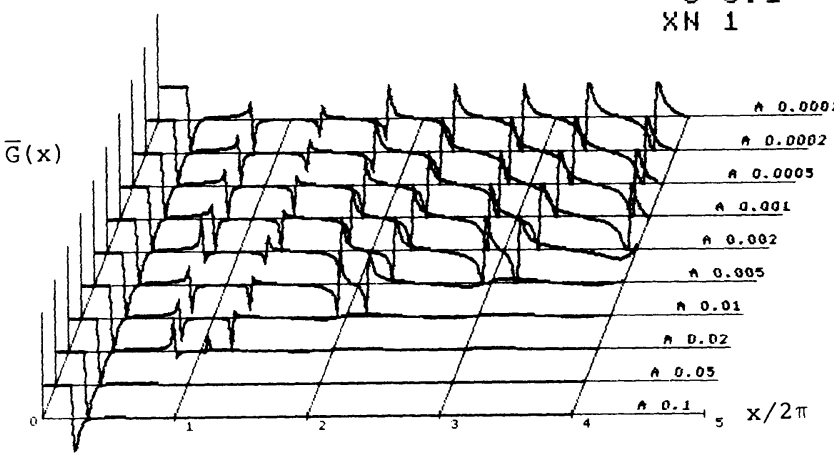

$$
\begin{aligned}
& \tilde{Y}_{1}=\frac{\sin x}{x^{2}}-\frac{\cos x}{x} \ldots \ldots \ldots \ldots \ldots \ldots \\
& d \tilde{Y}_{1}=-\frac{2-x^{2}}{x^{3}} \sin x+\frac{2}{x^{2}} \cos x
\end{aligned}
$$

のように式が書ける. $G(x)=0$ の条件より $A$ の值を定めると

$$
A=\frac{d \bar{X} \cdot \tilde{Y}_{1}-\bar{X} d \tilde{Y}_{1}}{\bar{X}-x d \bar{X}}
$$

が得られる.

$A$ の值は式（12）よりわかるごとく，粘 性減衰係数に相当しているので, $A$ の值が

Fig. 4 Relations between $\bar{G}(x)$ and parameters $A$ and $C$ 
小さいほよ゙,不安定となるわけである.したがって式(30) で決定をされる $A$ より小さい值をとる $x, C, x_{n}$ の組 合せが不安定条件を与えることになる。

そこで, 代表的に $C=0.1$ の場合の $x_{n}=1,2$ の各場 合の $A$ と $x$ のグラフを求めてみたのが Fig. 6 である. このグラフの縦軸は $A$ の值であり, 横軸は $x$ を表わし ている.

図中の赤の部分が, $\bar{G}(x)<0$ の領域であり, 不安定 の部分である.このグラフより次のようなことが判明す る.

1) $x=n, n=1,2,3$ の付近に不安定領域があり, $x>x_{n}$ の範囲では, 不安定領域が $x=n \sim x$ $=n+1 / 2$ に広がっており, $x<x_{n}$ の範囲で は, $x=n-1 / 2 \sim x=n$ の部分で不安定領域 が生じている.

2) $x=x_{n}$ のところでは, 不安定領域が広 がっており, $x=n-1 / 2 \sim x=1 / 2+n$ まで であり，ピークが2つ現われていることがわ かる.

3）系の固有振動之同じ振動周期で自励振 動の発生する条件は, $x=x_{n}$ の場合のグラフ

(Fig. 6 3) であり, $x_{n}=n, n=1,2, \cdots の$ ときに不安定になっていることがわかる。ま たこの場合には， $x=x_{n}=0.3$ 付近に，大き なピークを示す部分が現われている.

4）いずれの場合にも $x$ が大きくなるに 従って，不安定度は小さくなってゆく.

このように，部分的にみていては，全体的 な傾向がよくつかめないので, 三次元グラフ で，全体的な傾向をつかむことにする.

Fig. 7 に $x_{n}=1.25$ と $x_{n}=1$ の場合で, $C$ が 0.00001 より 10 まで変化させたときの状 況を三次元グラフで示してある.

縦軸は $A$ の值を対数表示したものであり, 0.001〜1 までの値を圧縮して示してある.

横軸は， $x$ の値である. グラフは奥の方か ら手前に向かって，Cの値を増加するよう にして表示してある. $C=1 \times 10^{m}, m=-5$ 〜2の場合のグラフは, 不安定部分を赤色に 塗って示してある.これ以外の中間部分のグ ラフは赤線のみで示してある.

中間のグラフの $C$ の值は, 対数グラフの $1 / 4,1 / 2,3 / 4$ の点に相当する, $1.8 \times 10^{m}$, $3.2 \times 10^{m}, 5.6 \times 10^{m}, m=-5 \sim 2$, の值で 計算している.

さて，このように三次元グラフにしてみる と, 非常に面白い傾向のあることがわかる.
1）Cの值の小さい領域では, 不安定領域の両サイ ドで，鋭いピークを示す部分がある.

また Cの值が大きくなると，この部分が消えて，丸 味をもった，領域の中央でピークをもつ傾向となる.

2) $C$ が 0.1 以下の部分では不安定領域が分裂し, または，分裂したものが，Cの増加に従って合体する ような, 渡りの現象が現われている.

このために, 全体としては $x=n, n=1,2, \cdots$ で不 安定にある傾向であるが, $x=n+1 / 4, x=n+1 / 2, x$ $=n+3 / 4$ でも不安定になる場合もでてきている.

3) $x_{n}=1.5,1.75$ 等の場合も求めてみたが, この渡
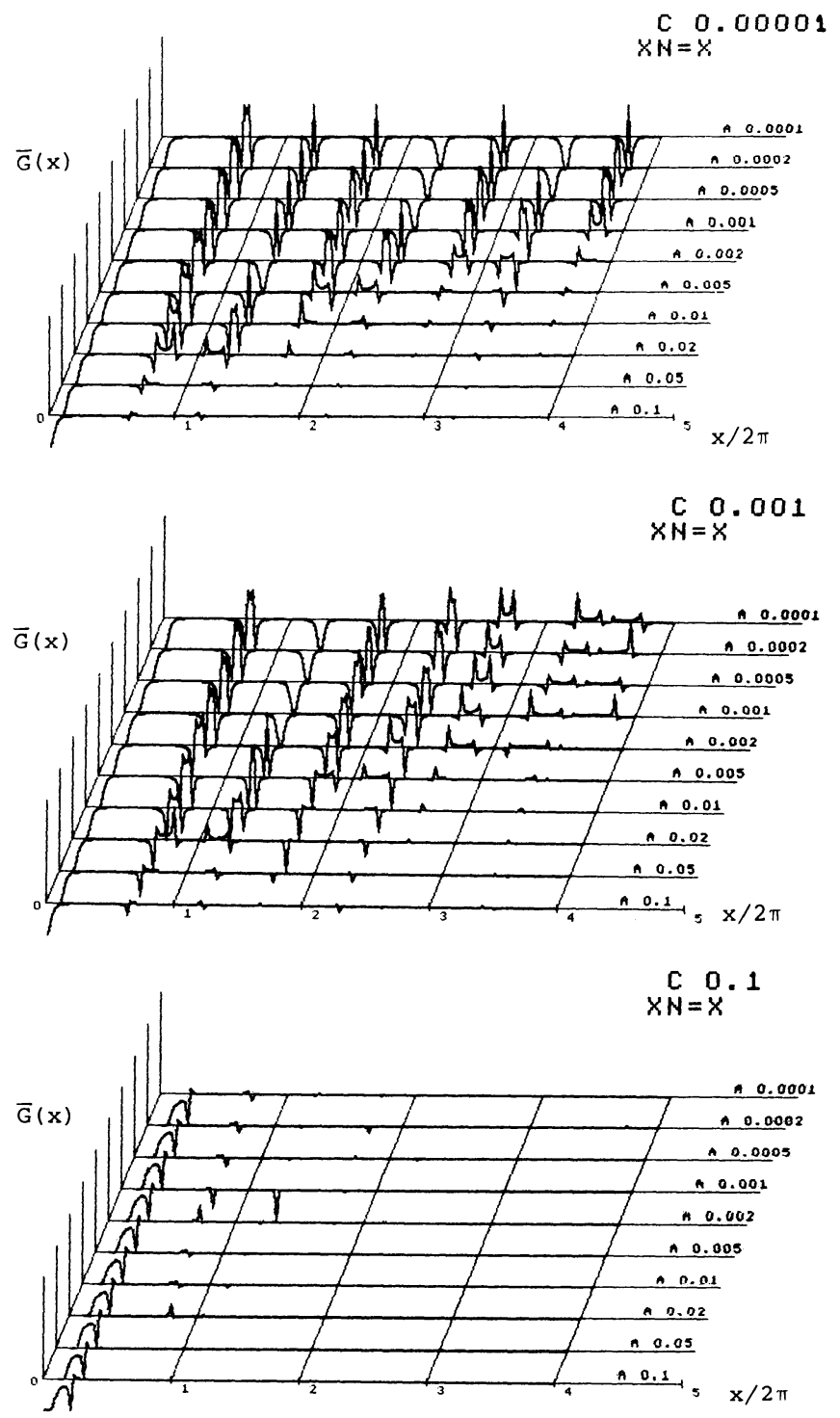

Fig. 5 Relations between $\bar{G}(x)$ and parameters $A$ and $C$ in the case with the same frequency of natural oscillation. 
りの現象は現われており, その分裂, 合体する $C$ の值 に若干のずれがある程度で, 全体の傾向は同じである.

このようにみてくると，この現象は非常に複雑である ことがわかる.

4) $x_{n}$ の影響は, $x>x_{n}$ では, 不安定領域が $x=n$, $n=1,2,3 \cdots$ の大きい方にずれ, $x<x_{n}$ の部分では, 小 さい方向にずれている.

また, $x=x_{n}$ の部分では不安定領域が広くなる傾向を 示している (Fig. 8).

1）不安定領域は, $x_{n}=x=n, n=1,2,3 \cdots$ で発生 しており, その前後 $\pm 1 / 2$ の範用に存在している.

2）Cの値が小さいときには, 不安定領域が広く, 值が大きくなるに従って狭くなってきている.

3） $C=0.001, x=3.5$ 付近で分裂した不安定領域は, $C=0.1, x=0.5$ 付近までに渡ってきている.

次にゲートの振動系が応答しないケースとして, $x_{n}$ $=0$ の場合について検討してみよう。これはちょうど ナップのみの脈動が起こっている場合に相当している.

Fig. 9 は, $C=0.1$ で $x_{n}=0$ の場合のグラフである.

1) $x=1 / 2$ でピークを示す不安定領域があり, $x=n$, $n=1,2,3 \cdots$ で不安定領域が発生している.

2) $x=n$ での不安定領域は, $n$ の若干小さい値より $n+1 / 2$ 付近まで広がっていることがわかる.

$C$ の值の全体の影響をみるために三次元グラフ表示 したのが, Fig.10である.これは先の Fig.7, Fig. 8 と 同じ形式で表現してある. また基本的な傾向は， $x_{n}=x$ の場合のグラフと同じであるが, 次のような点で傾向が 異なっている.

1）全体に不安定度は増加している. また不安定領域 の分裂合成が明確に現われており，合成された後には， なめらかな曲線形を示している.

2）不安定領域は $x=n, n=1,2,3 \cdots$ をはさんで両 側にあるが， $x=x_{n}$ の場合には， $x=n$ をほぼ中央にし て分布しているが, $x_{n}=0$ のケースにおいては, $C$ の小 さい値の部分では $x=n-1 / 4 \sim n+1 / 5$ で不安定とな り, $C$ の大きく, 不安定領域が合体した後では $x=n-$ $1 / 5 \sim n+1 / 2$ の範囲に存在しており,ずれが生ばている.

\section{5. 模型実験結果との関係}

実験で振動の発生した条件と,これらの解析結果の適 合性について検討してみよう。

Fig. 11 は, 模型実験によって, 自励振動の発生した 状態を, 水の落下時間と振動周期との関係で示したもの である. このときの模型の大きさは， $B=40 \mathrm{~cm}, l=20$ $\mathrm{cm}$ と $30 \mathrm{~cm}$ の 2つであり昭和 47〜 49 年にかけて実験 している.

これらの場合について式（4）および式（12）で与え
られる $C$ の值を求めてみた. 水の落下時間によってゲー トおよび，ナップ下の体積が異なってくるが，Fig.11 より自励振動の起こっている時間が $\beta=0.1 \sim 0.4 \mathrm{~s}$ であ るので,この範囲で考えてみることにする．結果は Table 1 のようになった.

これらの場合 $6 \times 10^{-4} \sim 2 \times 10^{-3}$ の範囲に存在してい ることがわかる.これを Fig. 8 の固有振動と同じ周期で 振動する自励振動の場合としてみると, グラフの上の中 心付近の $C=0.0001 \sim 0.01$ に相当していると考えてよ い.このグラフのピーク值を示す位置と, Fig. 11 の自 励振動の周期と, 落下時間とのグラフを比較してみると, よい相関を示していることがわかる.

すなわち, $X=0.5$ のピークは, Fig. 11 の $n=0.5$ に, $X=1.1$ のピークは $n=1$ に $X=1.7,2.2$ のピークは $n=2$ に $X=3.7$ 付近のピークは, $n=4$ に相当してい ることがわかる.

前回の解析では $n=0.5$ のケースの不安定条件が明確 につかめなかったが, 今回の解析によって明確にできた わけである.

また，H. Ivan Schwartzの提案した2)ナップの脈動に ついての法則 “ $K+1 / 4 ”$ についても, この解析結果が 適用できることがわかった.この法則は, 水脈が脈動す るときに, 落下開始点より, 下流水面までの間に $K+$ $1 / 4, K=1,2,3 \cdots$ の波が存在するときに脈動が発生す るというものである.この解析の場合ではゲートが, 圧 力変化に応答しない場合に相当しており, Fig. 10 の場 合に相当している.これでみればわかるごとく, $x=n$ $+0.2 \sim n+0.3$ の間にピークがあるのは明確であり, 特 にCの值が大きい場合には $n+1 / 4, n=1,2,3 \cdots$ で ピークを示しており，まったく“ $K+14 ”$ 法則に一致し ていることがわかる.

次に,この論文に討議を寄せている K. Petrikat と T.E. Unny は，ゲートのように弾性支持されている場 合には“ $K+3 / 4 ”$ 法則が成立し，E．Pariset が提案し ている“ $K+3 / 4+\beta ”, \beta=-0.2 \sim 0.1$ が広い範囲に適 用できるとしている.

このことは, Fig. 8 においては, $C$ の値が小さい 0.001 以下において, $x=n+0.7$ 付近にピークのあるこ とをみると, ちょうど $n+3 / 4, n=1,2,3 \cdots$ に相当し ており，また，Cの値が大きいところでも， $x$ の值が 小さいところでは, これが成立していることがわかる.

\begin{tabular}{c|c|c} 
Table 1 & \multicolumn{2}{c}{ ゲートの慣性モーメントおよび $C$ の值 } \\
\hline & $I$ & $C$ \\
\hline $\mathrm{S} 47$ & $3.66 \times 10^{\circ}$ & $(2.04 \sim 3.13) \times 10^{-3}$ \\
$\mathrm{~S} 48$ & $6.72 \times 10^{\circ}$ & $(5.93 \sim 11.3) \times 10^{-4}$ \\
$\mathrm{~S} 49$ & $9.2 \times 10^{4}$ & $(7.63 \sim 11.8) \times 10^{-4}$ \\
\hline & $\mathrm{g} \cdot \mathrm{cm}^{2}$ & \\
\hline
\end{tabular}



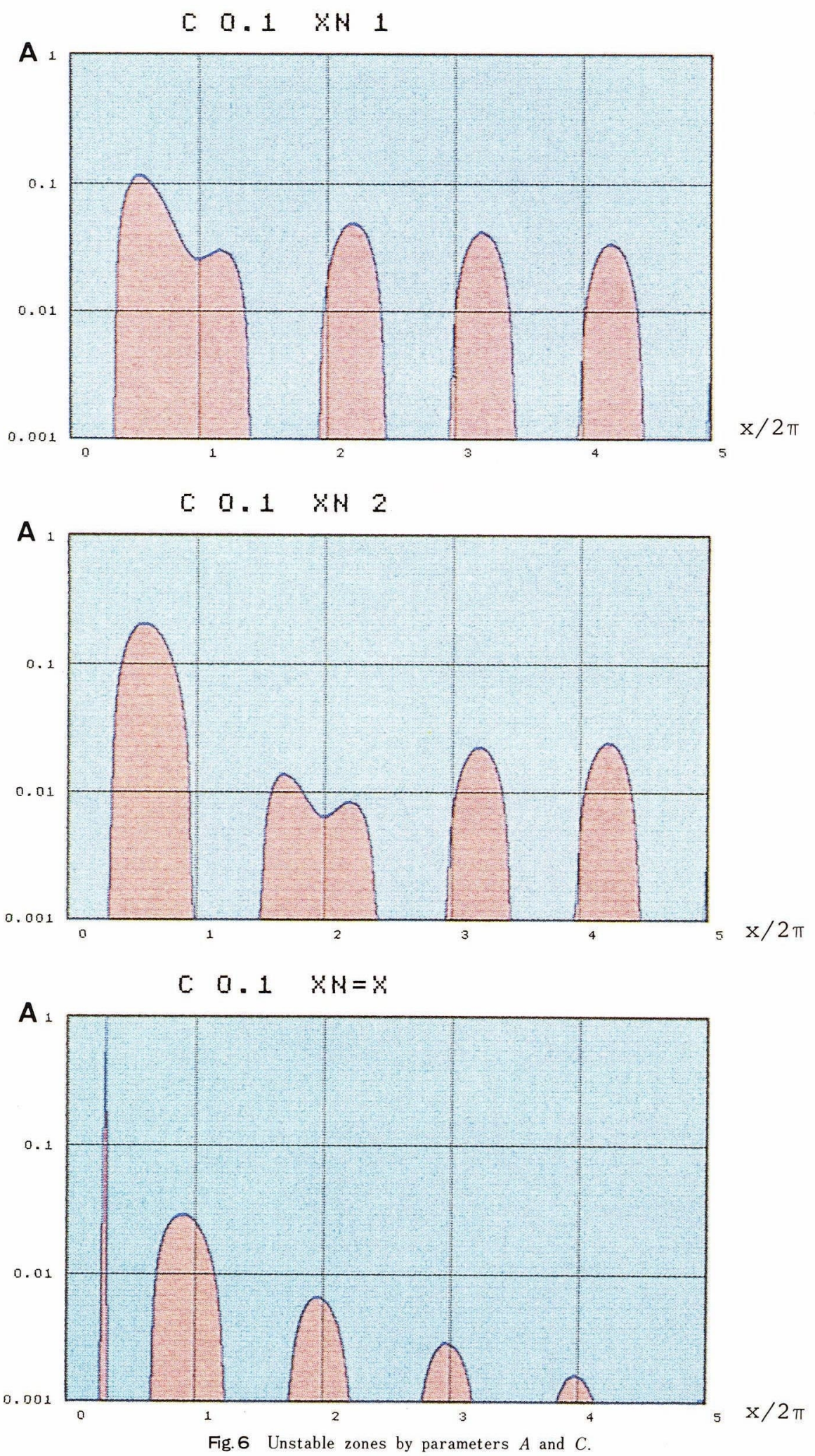

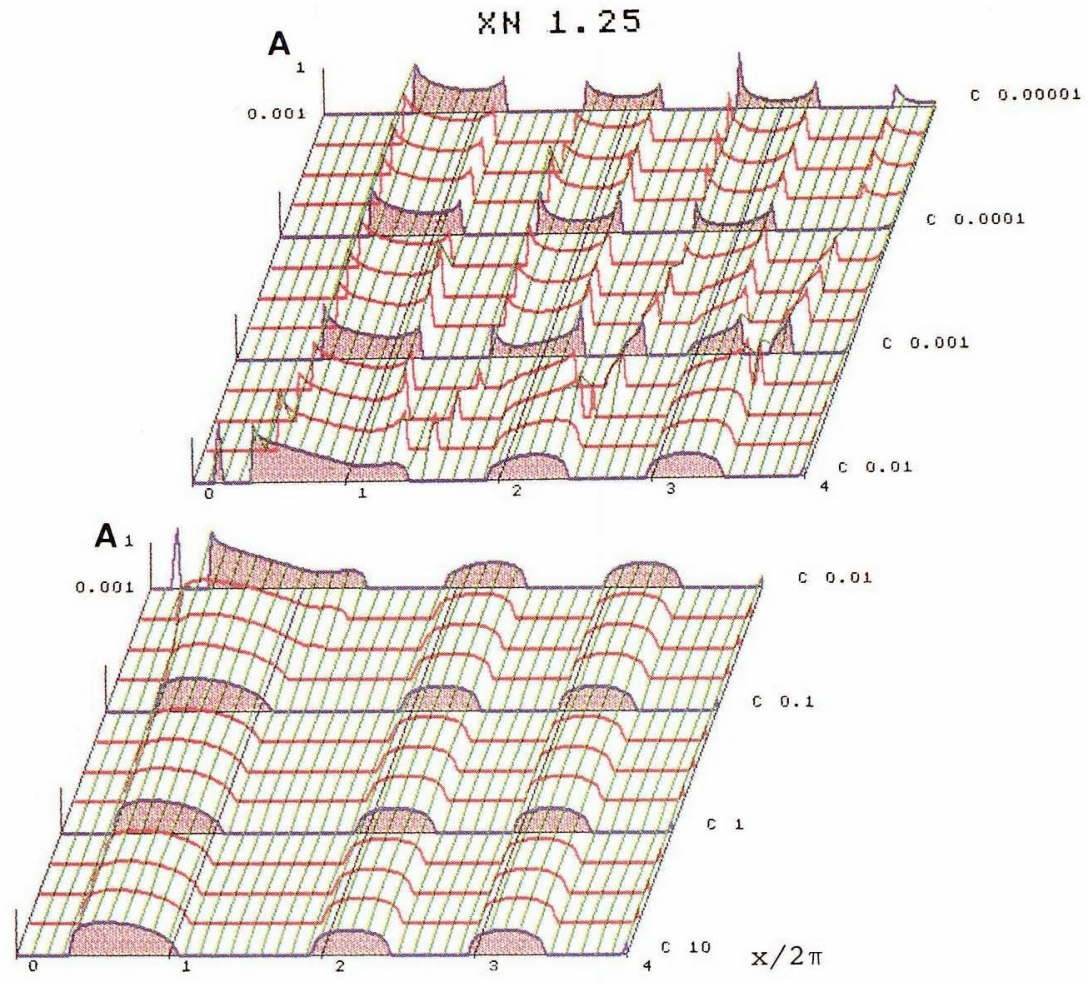

XH 1
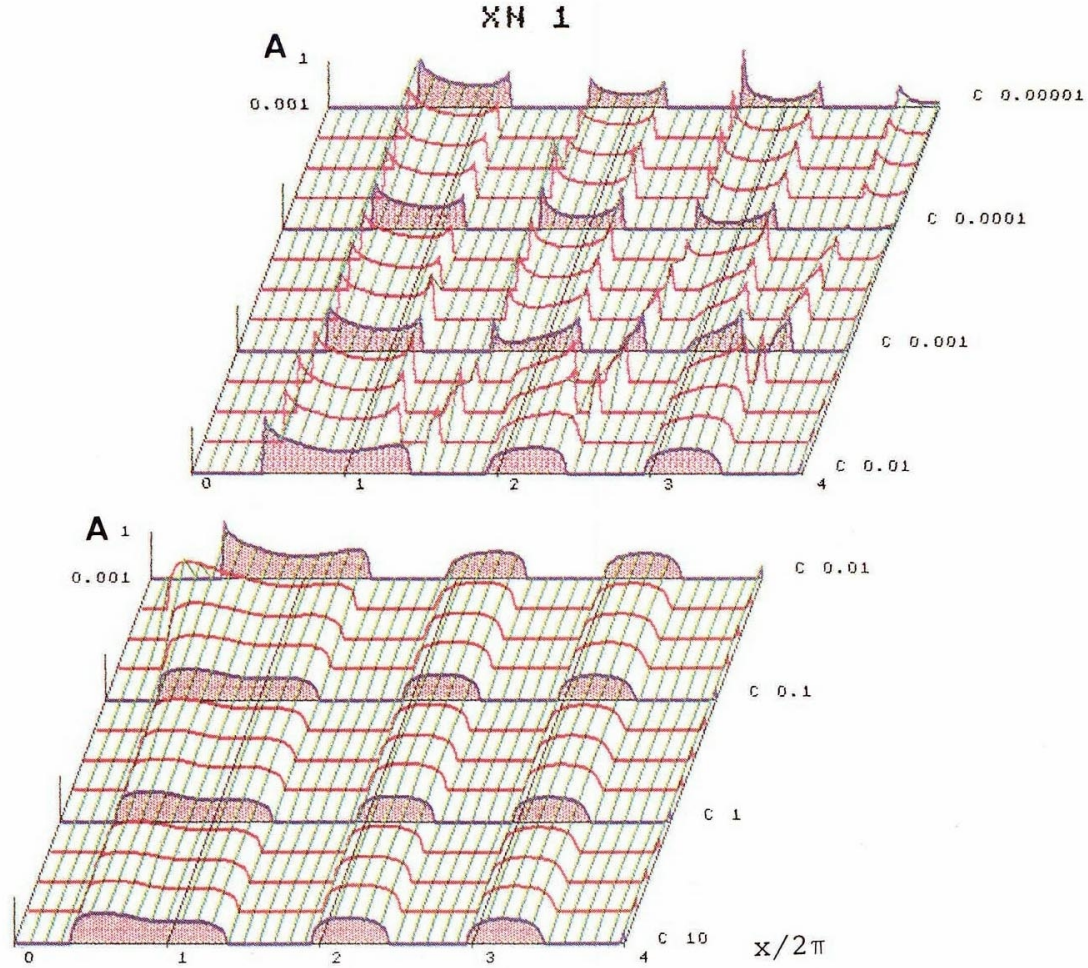

Fig. 7 Unstable conditions by all parameters $A, C$ and $x$. 

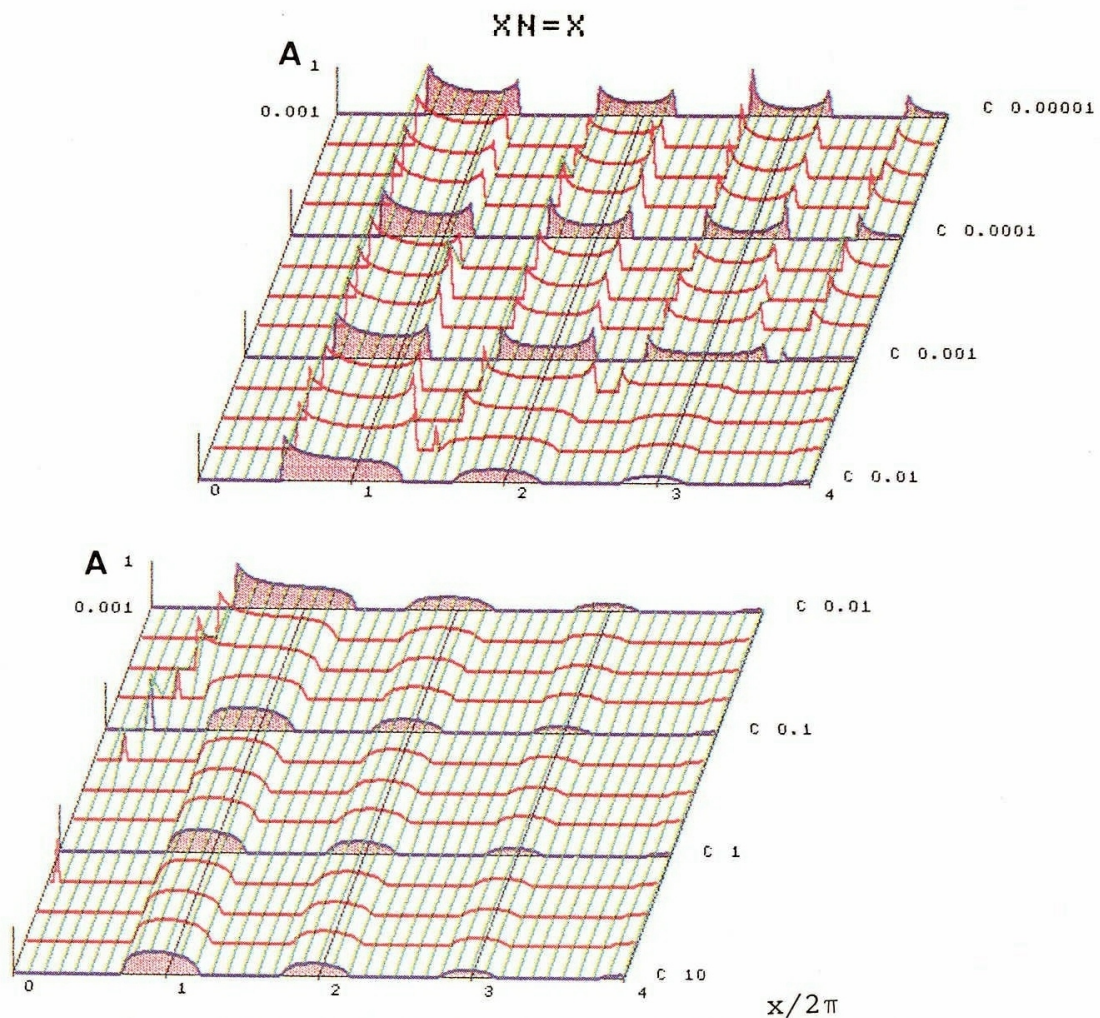

Fig. 8 Unstable conditions by all parameters $A, C$ and $x$ in same phase of natural frequency.

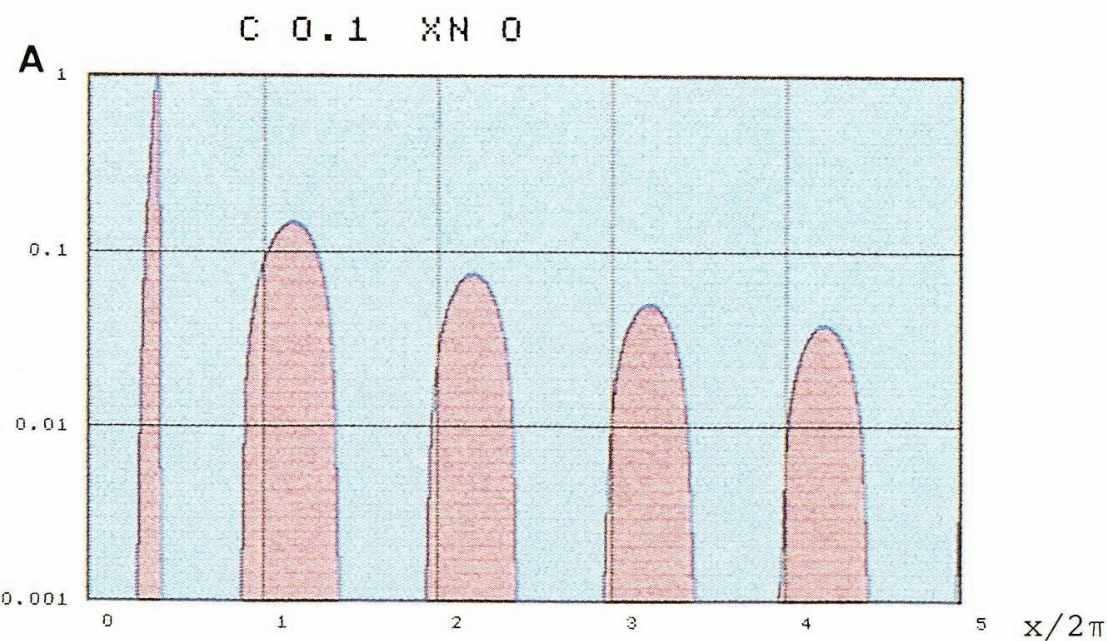

Fig. 9 Unstable zones by parameters $A$ and in $x_{n}$ is zero.

以上のように，ナップの関連した自励振動の発生条件 が，この解析手法によって説明できることがわかった.

\section{6. ま と め}

フラップゲー・トの自励振動が, 線形振動としての解析 手法によって明確にすることができた。この件について
は，以前に領域の組合せとして判断する手法とよって一 部については明確にすることができていたが，今回の手 法によって，その条件を明確にすることができ，先の解 析では明確にできなかった，H. Ivan Schwartzのナッ プに関する不安定条件をも，説明することができた. また, 不安定条件が, パラメーターの变化に応じて, 

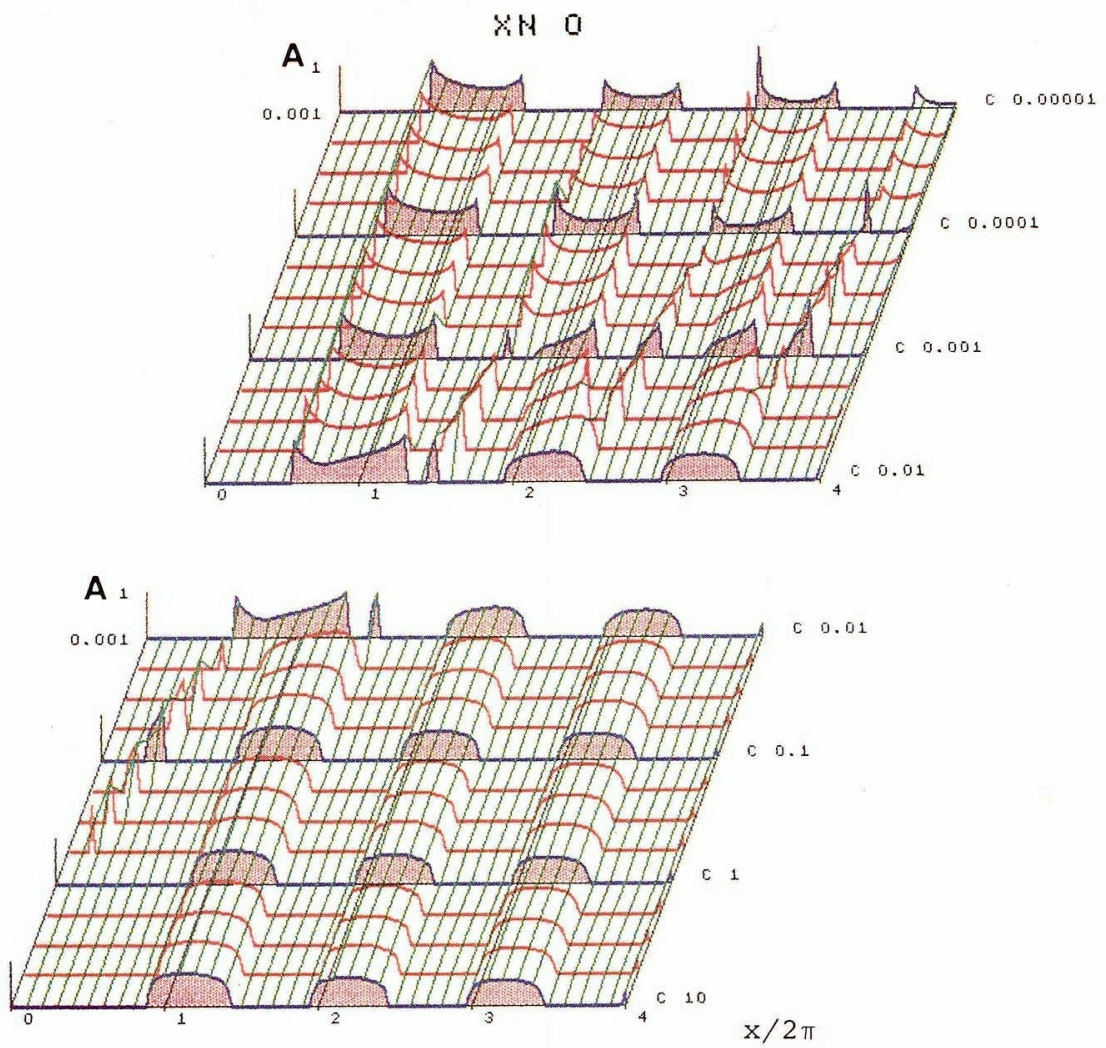

Fig. 10 Unstable conditions by all parameters $A, C$ and $x$ in the case $x_{n}$ is zero.

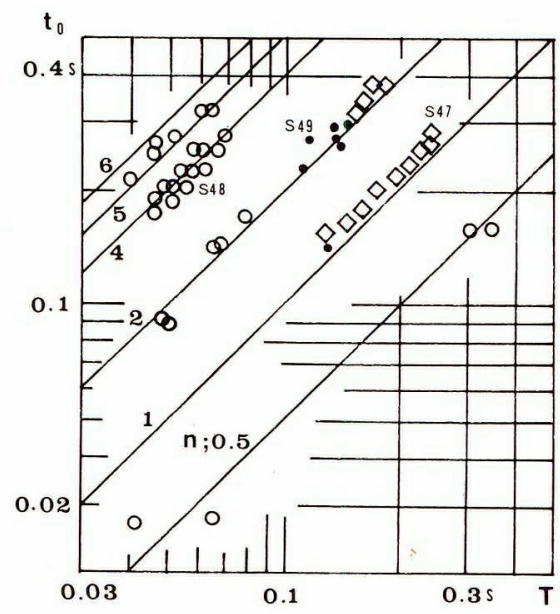

Fig.I I Experimental Results.

周波数領域で分裂したり，合流したりする現象が現われ ることがわかった。このようなことのため,このナップ の脈動に関連した現象の複雑さが起こっていると考えら れる.

今回ここで提案した手法は等角写像の考え方を利用し ており, 線形の不安定問題のみでなく, 非線形問題にも
使える方法であり, 機会をみて, その種の不安定問題に も利用したいと考えている.

\section{参 考文 献}

1）本間 仁・荻原国宏：フラップゲートの振動についての 理論解析, 土木学会論文報告集, 第 238 号, 1975-6.

2）本間 仁・荻原国宏：フラップゲートの自励振動につい て, 第 19 回土木学会水理講演会論文集, 1974.

3) Masashi Homma, Kunihiro Ogihara : Theoretical analysis of Flap Gate Oscillation, Transaction of JSCE, Vol. 7, 1975.

4) Masashi Homma, Kunihiro Ogihara: Theoretical analysis of Flap Gate Oscillation, (Subject C.c), Proc. of IAHR, 1977.

5) Kunihiro Ogihara, Sachihiko Ueda : Flap Gate Oscillation, IAHR/IUTAM Symposium, Practical Experiences with Flow-induced Vibrations, 1979.

6) H. Ivan Schwartz : Nappe Oscillation, Proc. of ASCE, Nov., 1964.

7) H. Ivan Schwartz: Edgetones and Nappe Oscillation, Jr. of the Acoustic Society of America, No. 3, 1966.

8) Petrikat, K. and Unny, T.E. : Discussion on Nappe Oscillation by H. Ivan Schwartz. Proc. of ASCE, Sept., 1965.

9) Eduard Naudascher : Discussion on Nappe Oscillation by H. Ivan Schwartz, Proc. of ASCE, May, 1965.

(1984.6.1 - 受付) 